Danielle Bartoni is a second year MPA student with a concentration in environmental policy and urban planning. While attendins The George Washington University, Ms. Bartoni has recelved a tederal bellowship and an academic scholarship which has enabled and inspired her to continue her studies in environmental policy Ms. Bartoni is currently working as an intern for the Environmental Protection Agency in the Pollution Prevention Division and the Washington Metropolitan Council of Governments in the Transportation Planning loivision. In 1998. Ms. Bartoni was admilted into Pi Alpha Alpha the honor society for public abfairs and administration.

\section{Life, Liberty, and the Pursuit of Mobility: Putting a Price on Traffic}

\author{
Danielle Bartoni
}

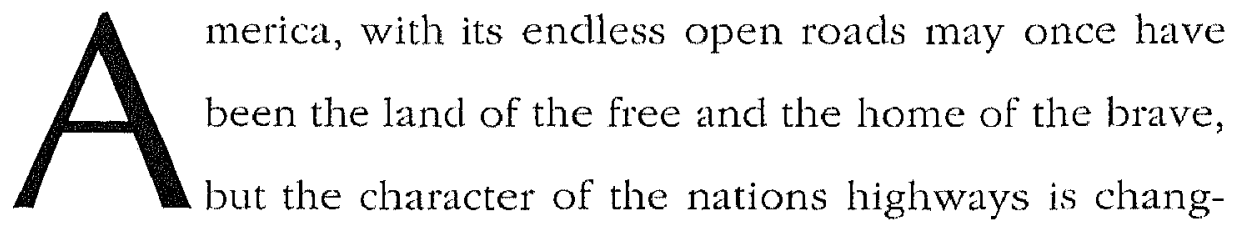
ing. In the area of traffic, America feels more like the land of the congested and home of the enraged.

Overcrowded roadways have become a national nightmare, resulting in missed opportunities, tardy arrivals, and dangerous delays. Traffic jams are hardly a minor annoyance: in 1991, the Federal Highway Administration estimated that more than 65 percent of urban freeways were congested during peak hours while in 1993 the cost of traffic delay in urban areas alone totaled $\$ 51$ billion. ${ }^{2}$

For years, a variety of public policy analysts - including economists, traffic planners, and city designers-have agreed that the only way to curb highway congestion is by charging motorists a fee to drive. However, implementing user fees is politically unpopular; few politicians like to inform taxpayers of an increase in costs to 


\section{Most Americans}

believe that

driving is an

\section{inherent right for}

which no fee

should be

charged-hence

the term

freeways. use a public road. Moreover, most Americans believe that driving is an inherent right for which no fee should be charged-hence the term freeways-and do not believe that they should ever have to pay to use the public roads. In fact, many motorists feel that they have already paid their fair share for road services through taxes on gas, sales, and income and are unwilling to pay more. However, contrary to these popular beliefs, imposing user fees are more than justifiable; such fees are critical to preserving the use of existing roadways as a viable transportation option in the future.

Conventional transportation policies, or supply-side policies, attempt to relieve traffic congestion by increasing the carrying capacity of roadways to accommodate more motorists. However, the continued expansion of roadways has failed to

keep pace with the increasing number of drivers. Despite figures showing that total miles driven per day have increased twice as fast as roadway capacity, ${ }^{3}$ policymakers continue to follow the same supply-side policies of expanding and creating new roadways. Ironically, these policies designed to reduce congestion have only made the problem worse.

Fortunately, motorists are not doomed to sit in traffic and stare at an endless line of brake lights. Traffic congestion is manageable and can be significantly reduced through demand-side transportation policies that modify motorists' behavior to meet the capacity levels of current roadways. One demand-side policy, congestion pricing, charges drivers a fee for using the roads during peak traffic hours, carrying a built-in incentive to motorists to travel during off-peak hours.

This article examines the applications of a form of congestion pricing known as value pricing and advocates the further implementation of value pricing by state and federal officials. The Washington, DC metropolitan area could reap substantial benefits from value pricing, since this area has consistently been rated one of the most congested localities in the nation by several studies, ${ }^{4}$ but value pricing is not a popular option in Washington, as the response to a plan to relieve congestion on the Woodrow Wilson Bridge shows. Finally, this article offers a cautious forecast for the future success of value pricing. 
The Costs of Congestion: From Road Rage to Lost Business

Roadways can only accommodate a limited number of vehicles. Once roadways exceed maximum carrying capacities, each additional vehicle significantly recluces the flow of traffic by decreasing the average speed of all vehicles, ultimately creating gridlock. More than 65 percent of urban freeways are congested during the peak hours of 6 to $9 \mathrm{a} . \mathrm{m}$, and 4 to 7 p.m. ${ }^{5}$

Relocation outsicle urban areas has expanded traffic problems beyond the city and into suburban America, Recent studies indicate that one reason people move to suburban areas is to escape the costs of traffic congestion. ${ }^{6}$ But suburban residents, lacking public transportation, are more dependent on their cars than urban residents, so suburban areas and small communities are experiencing traffic jams that are just as frustrating and time-consuming as those in the city,

Driving an automobile during congested periods of travel is costly for both the driver and the environment. Drivers in the Washington, DC metropolitan area alone will lose 100 hours per year by sitting in traffic, resulting in $\$ 2,115$ of foregone income per year. ${ }^{7}$ Traffic congestion also adds unnecessary stress on individuals who travel cluring peak periods and is the underlying cause of the new phenomena referred to as "aggressive driver syndrome." Between 1990 and 1995, the American Automobile Association reported a 51 percent increase in incidents of "road rage"; more than 200 of those incidents ended in death. ${ }^{8}$ Additionally, air and noise pollution damage the environments surrounding congested roadways. In 1996, drivers in Washington, DC wasted more fuel per capita than drivers in any other city in the nation, with each resiclent burning an additional 60 gallons of gasoline due to gridlock. ${ }^{9}$

The social costs of traffic congestion are accompanied by an economic burden. Customers may find non-congested areas in which to shop but the increased costs of hauling goods via roadways are still passed on to consumers through higher prices. By the year 2020, traffic congestion will more than quadruple delivery costs in the Washington DC metropolitan area. ${ }^{10}$ The increase in cost to consumers could be as much as $\$ 1,365$ per household, per year. ${ }^{11}$

\section{Replacing Supply-Side Transportation Policies}

A variety of traditional methods are currently used to increase the carrying capacity of roadways, including synchronized traffic signals, programmed repair and maintenance of roadways, roving repair vehicles to clear accidents quickly, conversion of two-way streets to one-way streets, and monitor signals controlling the flow of vehicles entering roadways. ${ }^{12}$ None of these methods have been effective in reducing the number of vehicles on roadways. Additionally, creating more highways is counterproductive since motorists, attracted
The continued

expansion of

roadways has

failed to keep

pace with the

increasing

number of

drivers. 
Drivers in the

Washington, DC

metropolitan area

alone will lose

100 hours per

year by sitting in

traffic, resulting

in $\$ 2,115$ of

foregone income

per year. to what they think will be uncongested roadways, end up stuck in traffic with all the other drivers who mistakenly thought that more roadways meant less congestion. ${ }^{13}$

Congestion pricing works on principles that are entirely different from traditional supply-side policies. By charging higher prices during peak hours, congestion pricing has reduced the use of limited commodities and shifted consumer demand in a variety of industries. For instance, the telephone and electricity industries charge higher rates during periods of substantial use to ensure system stability. The benefits are apparent: telephone calls made during the day cost more than calls made at other times so customers make calls during less expensive calling times (evenings and weekends) which in turn reduces the demand on the telephone network during the day. Movie theatres offer discounts for afternoon shows to attract people away from evening attendance and the "Sold Out" sign in the box office window on a weekend evening. Even restaurants offer "early bird" specials to attract diners to off-peak hours. Similarly, using the roadways should carry a fee that reflects the costs of constructing and maintaining facilities, the costs related to traffic congestion, and the demands by drivers for a place on the roads. ${ }^{14}$

Value pricing, one type of congestion pricing, requires motorists using high-traffic roads to pay a fee for the privilege of driving. Congestion pricing charges all drivers for travel- ling during peak hours; value pricing is more selective, charging only solo drivers who drive in High Occupancy Vehicle (HOV) lanes. Normally, HOV lands can only be used by cars carrying several occupants; converting HOV lanes to High Occupancy Toll (HOT) lanes lets drivers onto major roads only by paying a fee.

HOV lanes are converted into High Occupancy Toll (HOT) lanes through the use of Electronic Toll Collection (ETC) systems or Automatic Vehicle Identification (AVI) systems, both of which automatically deduct tolls from an electronic account. The electronic accounts are established through the use of a transmitter that can be attached to a vehicle's dashboard or windshield. A roadside antenna releases a signal that records the account number from the transmitter along with the toll amount. Rather than stopping at a toll booth to deposit money, the driver has the fee automatically deducted from an account; even some toll facilities, such as bridges and turnpikes, have installed ETC and AVI systems.

Most HOT facilities use prepaid monthly accounts for billing and require initial security deposits of approximately $\$ 40$ to cover the costs of distributing the transmitters. When accounts reach a minimum level, motorists are alerted by mail or by a flashing light or other signal when entering a HOT facility. And the systems are difficult to evade: the toll collection mechanisms can record account numbers on cars travelling over 100 miles per hour. 
Many HOT facilities (and other users of ETC systems) are equipped with cameras located at entry and exit points in order to prevent nonequipped ETC solo motorists from using the restricted facility. License plate pictures can then be matched with state motor vehicle registration records, and violating motorists can be fined accordingly.

Many solo drivers complain that the creation of HOV lanes have actually caused more traffic congestion by forcing all one-driver automobiles, which make up the majority of rush hour traffic, onto a decreased number of lanes. ${ }^{15}$ However, HOT lanes can equalize the number of cars on HOV facilities while generating money to be used for the expansion of public transportation and the continued support of ridesharing; this concept is known as "HOV-Buy In" since the policy is based on selling the unused capacity of HOV lanes to a set number of registered solo drivers for a fee. In the case of HOV facilities that are near capacity, HOT lanes have also proven useful in maintaining the efficient flow of traffic through variable pricing that fluctuates during the day according to the congestion on the road.

\section{Current Implementation}

The Intermodal Surface Transportation Efficiency Act of 1991 (Public Law 102-240) has created new opportunities for the implementation of value pricing by removing the federal prohibition against charging a toll on interstate highways. Under the Con- gestion Pricing Pilot Program, which was created by this law, HOT lanes are being examined as a way to reduce congestion.

Interstate-15 HOV lanes in San Diego, the California State Route 91 HOT lanes in Los Angeles County, and Interstate-10 (Katy) HOV Lanes in Houston, Texas, are three examples of the successful implementation of value pricing.

\section{I-15 HOV Lanes: San Diego, California}

In 1996, North San Diego County, California opened an eight-mile stretch of an underutilized two-lane HOV facility on the Interstate- 15 highway to solo drivers who bought an "ExpressPass"; two years later, the passes were replaced by windshieldmounted electric transponders. Initially, 500 solo drivers subscribed to the project for $\$ 50$ a month; in March, 1997, the fee was raised to $\$ 70$ per month for more than 900 ExpressPass drivers. ${ }^{16}$ In February 1998 , variable trip tolls ranged from $\$ .50$ to $\$ 4.00$ for solo and HOV-2 drivers. ${ }^{17}$ By November, 1997, less than two years after their inception, HOT lanes on the San Diego's Interstate 15 had generated enough revenue to launch a new express bus service. ${ }^{18}$

The North San Diego County project is evidence that a well-designed value pricing system will attract drivers who are willing to pay for access to noncongested roadways. Interstate 15 used a flat monthly fee in the initial stages of the HOT lanes projects, making it easier for motorists to understand the program, before moving

\section{The American}

Automobile

Association

reported a 51

percent increase

in incidents of

"road rage";

more than 200 of

those incidents

ended in death. 
"HOV-Buy $I n "$ is

based on selling

the unused

capacity of HOV

lanes to a set

number of

registered solo

drivers for a fee. to higher tolls during peak travel times to control the flow of traffic. The success of the program was virtually assured when Expresspass users reported saving 10 to $20 \mathrm{~min}$ utes per trip. ${ }^{19}$ And travelling in HOT lanes clearly proved to be more costeffective than being clelayed; of the original users of the Express Pass system, 84 percent remained after the fee was raised. Additionally, the California State Department of Transportation indicates that peak periods of travel on the parallel general purpose lanes have improved, ${ }^{20}$

\section{State Route 91 Express Lanes: Orange County, California}

HOT lanes can be helpful in reducing the congestion in HOV lanes that are near maximum capacity levels. California State Route 91, which began service in 1995, was the country's first privately owned, fully automated, value-priced transportation system. State Route 91 is a 10-mile facility with two toll lanes in each direction that was built in the median of an existing eight-lane freeway and is one of the busiest stretches of highway in Los Angeles County and, for that matter, the world. ${ }^{21}$

Currently, 86,000 motorists have transmitters which allow them to travel on State Route $91 .{ }^{22}$ Tolls for solo drivers range from $\$ 0.60$ to $\$ 2.95$ per trip and are automatically deducted from a prepaid account linked to the transmitter. ${ }^{23}$ Vehicles with three or more passengers travel in the express lanes for free. ${ }^{24}$ Just under 50 percent of express lane drivers use the facility once a week or less, illustrating that motorists will pay a fee when saving time justifies paying the toll. ${ }^{25}$ Toll rates are posted before the facility so motorists can choose to pay the price for the expedited trip.

In the ared of HOT lanes, success apparently breeds more success: an increased toll (from $\$ 2.50$ to $\$ 2.75$ per trip) resulted in an increase of 6,000 HOV-3 trips per week on State Route 91.26 And to make sure that drivers abide by the rules, more than 35 cameras operate along the ten-mile facility. First-time toll-jumpers are fined $\$ 15$, second-time offenders are fined $\$ 200$ and third-time offenders are fined $\$ 300.27$

The California and U.S. Department of Transportation are involved in a public-private partnership to encourage corporations to build, operate, and generate revenues for the Express HOT Lanes on State Route91. The California Private Transportation Company (CPTC) has thirty-five years to return a profit, during which time CPTC can set tolls accordingly (with a maximum rate of return agreement with the state). After thirtyfive years, the facility will be returned to California.

The HOT lanes have been profitable. State Route 91 had reportedrevenues totaling $\$ 7.07$ million and an operating income of more than $\$ 730,000$ during its first year of full operation. ${ }^{28}$ The California Private Transportation Corporation, operators of the private HOT facility, believe that tolls will eventually cover operating costs and provide a 17 percent return on investment, 29 


\section{Interstate-10 (Katy) HOT Lane:}

\section{Houston, Texas}

The Katy HOT lane is a reversible 13-mile HOV facility located in the median of the existing highway. Katy is the only HOT facility that allows variable occupancy levels during the day; three or more passengers per vehicle are required from $6: 45$ to $8: 00$ a.m. and 5:00 to 6:00 p.m. However, 300 vehicles with two passengers are allowed to use the facility for the fee of $\$ 2.00$ per trip. ${ }^{30}$ The Katy HOT facility is also looking to base its pricing on "real time" congestion levels charging motorists a fee based on current traffic levels in the HOT lanes rather than a set fee based on estimated peak and non-peak hours.

\section{The Value Pricing Option in Washington, DC}

Despite the successful implementation of value pricing in the jurisdictions described above, value pricing was firmly rejected as an option in Washington, DC.

A group of analysts recently concluded a four-year study of the Woodrow Wilson Bridge in Washington, DC that was undertaken in response to regional growth and transportation forecasts. Designed in 1951, the bridge was originally intended to act as a bypass around Washington, DC for interstate travelers. Today, the bridge averages 170,000 vehicles a day, twice its original carrying capacity, with 85 percent of the traffic made up of DC commuter traffic. 31
Current forecasts for the region predict that travel demand for the bridge and nearby area roads will only increase. By the year 2020, it is anticipated that the bridge will have to accommodate twice the number of cars for which it was built since demand for driving will increase by 70 percent in the region. Moreover, costs associated with the predicted traffic congestion in the area will also rise substantially, costing residents an estimated $\$ 2,115$ a year.

Based on these numbers, local officials agreed on a plan that calls for two sicle-by-side drawbridges with a total of twelve lanes to replace the current six-lane bridge. Each of the new bridges will have four general use lanes, one HOV lane, and one merging lane for each clirection.

Projections indicate, however, that expanding the Woodrow Wilson Bridge by six lanes will not sufficiently meet the travel needs of motorists. In fact, studies indicate a 16- to 18 lane bridge will be required to accommodate the expected travel growth for the year 2020 and beyond, 32 Rather than spending $\$ 1.8$ billion 33 on a 12-lane bridge that forecasts indicate will be obsolete by the year 2020, policymakers should consider a value pricing system to curb additional traffic; in fact, a congestion pricing analysis was conducted on the bridge that showed that 25,000 fewer vehicles would use the bridge per day if a $\$ 1$ toll for vehicles was implemented. 34
Despite the

successful

implementation

of value pricing

in [other]

jurisdictions, value pricing was

firmly rejected as

an option in

Washington, DC. 
Studies indicate a

16- to 18-lane

bridge will be

required to

accommodate

the expected

travel growth for

the year 2020

and beyond.

\section{Benefits and Detriments of Value Pricing}

Quantifying the costs and savings related to HOT lanes can be difficult since motorists value their time differently. Doctors trying reach the scene of an emergency or parents trying to get to daycare centers before they are charged a hefty late fee are people who care more about the penalties of missed deadlines than the cost of driving.

Some policymakers are concerned that if too many HOV lanes are converted to HOT lanes, congestion will worsen in unrestricted lanes which will, in turn, force more motorists to use HOT lanes, thus reducing the ease of travelling in HOT lanes. However, when HOT lanes are implemented, motorists appreciate the ease of driving, despite the costs, on roads that monitor and control the flow of traffic. Additionally, those drivers who choose not to pay the fee to use the HOT lanes will use public transportation, increasing the revenue of that service, or will use carpools.

The effectiveness of value pricing could be harmed by corporate travel expense subsidization, which would make the increased costs irrelevant to motorists and cause an inordinate proportion of single-driver vehicles to use HOT lanes. If higher costs of travel during peak travel times are irrelevant to motorists, the policy will not change travel behavior and its attraction will be diminished. To avoid this problem, businesses need to supplement ridesharing programs by providing business vanpools or transit subsidies rather than by reimbursing employees for any transportation expenses incurred.

Although value pricing has been proven to be effective in reducing traffic congestion, some argue that the policy is unfair because lower- income drivers will contribute a larger percentage of their income to such tolls than higher-income motorists, making the policy a form of regressive taxation. For instance, one survey of the HOT lane users on San Diego's Interstate 15 found that half of the respondents had annual incomes of $\$ 75,000$ or more, 29 percent earned between $\$ 40,000$ and $\$ 75,000$ and four percent had incomes of less than $\$ 40,000.35$ However, other surveys have indicated that motorists using HOT lanes in California are similar to those motorists using unrestricted lanes. 36

Since the use of HOT lanes is based on the value of time, not income, all income levels can benefit from using faster roadway service. Moreover, although value pricing is regressive, lower-income people usually drive less, on average, than those with higher incomes. ${ }^{37}$ In addition, lower-income groups usually reside within city limits, potentially limiting the use of HOT facilities. 38

Additionally, value pricing also makes alternative forms of mass transit, such as taxis, buses and vanpools, more effective. Revenues collected from HOT lanes will allow metropolitan areas to reinvest in current and future transportation needs, such as 
subways, light rail systems and bus routes, making these systems more efficient and attractive; in fact, if one percent of all suburban commuter trips, which account for 16 percent of all work trips, switched to mass transit, demand for mass transit would increase by 422,000 trips daily-and reduce road congestion by a corresponding amount. Investment and expansion of alternative transportation systems would also significantly benefit the mobility of non-drivers. 39

Although there are some inequalities associated with value pricing, most situlations are self-correcting. While on the surface, HOT lanes may seem to disproportionately benefit wealthier drivers, the effects of value pricing more than make up for any flaw in the system. Moreover, greater revenues and increased opportunities for infrastructure development make value pricing an overall equitable venture.

But despite its benefits, congestion pricing is not always popular with the public. In 1994, a congestion-pricing proposal of the San Francisco - Oakland Bay Bridge determined that the implementation of a $\$ 3$ toll for west bound traffic during the hours of $6 \mathrm{a} . \mathrm{m}$. to 9:30 a.m. and 3 p.m. to 6 p.m. for automobiles with two occupants or less would reduce delays by almost half (from a 20minute to a 12 -minute delay in the morning and from a 15 -minute to an 8 -minute delay in the evening). 40 Additionally, $\$ 22$ million would be collected in revenues annually from the increase in tolls, which would be used to support mass transit, ridesharing and other transportation services in the area ${ }^{41}$ Despite such appealing findings, the congestion pricing project was not undertaken since politicians were reluctant to enact legislation that could have been perceived as a tax increase.

\section{Conclusion}

No sane motorist would actually choose to sit in traffic if a viable alternative were available. Yet on a daily basis, drivers watch roadways turn into parking lots and are reluctant to change their driving behavior. Instead, motorists have accommodated traffic congestion by turning cars into mobile offices complete with CD players, cellular phones and lap top computers.

Motorists do not have to be stuck behind the wheel. Innovations such as value pricing and the Electronic Toll Collection (ETC) illustrate that motorists are not condemned to endure current (and increasing) levels of congestion. Significant increases in traffic flows can be made if policymakers and motorists, alike, are willing to take the first steps. To do so, motorists must begin to place a higher value their time raher than on "free" roadways. Likewise, policymaker's must acknowledge the benefits associated with value pricing. $\$$.

\section{Greater revenues}

and increased

opportunities for

infrastructure

development

make value

pricing an overall

equitable

venture. 


\section{Notes}

\begin{abstract}
1 Randall Guensler and Daniel Sperling, "Congestion Pricing \& Motor Vehicle Emissions: An initial review," Curbing Gridlock: Peak-period fees to relieve traffic congestion, vol. 2 (Washington, DC:National Academy Press, 1994), 356.
\end{abstract}

2 Based on estimates of motorists' value of time, delay in freight movement and wasted fuel for fifty large and medium-sized urban areas in 1993. Study sponsored by the Texas Transportation Institute. See Jolin T. Berg "The Congestion Pricing Pilot Program: Experience and Prospects," (Washington, DC:Highway Revenue and Pricing Team, Office of Policy, Federal Highway Administration, 1997), 1.

3 Comparison of the changes in daily miles traveled by inclividual motorists and the changes in additional lane miles built for expressways and major arteries in thirty-nine urban areas from 1982-1988. Source: The Texas Transportation Institute, See Anthony Downs, Stuck in Traffic: Coping with peakbour traffic congestion, (Washington, DC: The Brookings Institution, 1992), 11.

${ }^{4}$ See Downs, Stuck In Traffic, 1; Robert O'Harrow, Jr., "Study Says Area Drivers Loose 100 Hours, \$2,115 a Year," The Wrasbington Post, 24 December 1997; available from http://www.washingtonpost. com/wp-srv/local/ daily/april/24/botreport. html, 1; Alice Reid "Area Traffic Stuck in Costly Jam," The Washington Post, 10 December 1996; available from http://www. washingtonpost,com/wps.../growth/transport/long-conmute.html, 1.

5 Guensler and Sperling, Curbing Gridlock, 356 .

${ }^{6}$ Downs, Stuck in Traffic, 18.

7 Costs based on time and amount of gasoline used. See O'Harrow, "Study Says Area Drivers Loose 100 Hours, \$2,115 a Year,"; http://www,washingtonpost,com/wpsrv/local/daily/april/24/botreport.html, 1.

8 U.S News and World Report (6/2/97), available from http://www.drivers.com/ issues/roadrage/2driv.htm. (cited 18 Apri] 1998).
9 Annual federal study of the Washington Metropolitan area. Based on per capita costs. Study also indicates that Washington drivers waste the largest amount of time sitting in traffic, See Reid, "Area Traffic Stuck in a Costly Jam,"; http://www.washingtonpost.com/wps.../growth/transport/long-commute.html, 1 .

${ }^{10}$ A recent study sponsored by the Greater Washington Boarci of Trade. See O'Harrow, "Study Says Area Drivers Lose 100 Hours, $\$ 2,115$ a Year, ";http://www.washingtonpost. com/wp-srv/local/daily/april/24/botreport. html, 1.

11 Numbers reflect the prediction of costs to be imposed on the Washington, DC metropolitan area for products hauled into the region via roadways by the year 2020 .

See O'Harrow, "Study Salys Area Drivers Loose 100 Hours, \$2,115 a Year,"; http://www,washingtonpost.com/wp srv/local/daily/april/24/bot.html, 1.

12 Downs, Stuck in Traffic, 38.

13 Ibid, 11.

14 Fielding, 245.

15 Ibid.

16 The fee was raised an additional $\$ 20$ in March 1997 to account for the additional demand. See Federal Highway Administration, Transportation Studies Division, Highway Revenue and Pricing Team, "Congestion Pricing Pilot Program," Overview and Status Report, (Washington DC: Federal Highway Administration, Transportation Studies Division, Highway Revenue and Pricing Team, July 1997), 6.

17 In extreme cases, when heavy congestion in general purpose lanes results in the overcrowding of HOT facilities tolls will jump to a maximum of $\$ 8.00$ in increments of $\$ 1.00$. See Innovation Briefs, March/April 1998, 2.

18 C. Kenneth Orski, Eclitor, Innovation Briefs and Chair of Institue of Transportation Engineers Task Force on HOT Lanes, Briefing on the ITE Report, "High-Occupancy/Toll Lane and Value Pricing; A Preliminary Assessment," to the Metropolitan Washington Council of Governments, Transportation Planning Board Meeting, March 18, 1998. 
19 According to a survey of Interstate 15 drivers. See: Innovation Briefs, March/April 1998), 1. See Congestion Pricing Notes, 1.

20 Berg, "The Congestion Pricing Pilot Program: Experience and Prospects," 6.

21 B. Drummond Ayers, Jr., "A Toll Road in California Offers a High-Tech Answer to Traffic," The New York Times, 2 January, 1996, A1.

22 "Congestion Pricing Pilot Program," Overview and Status Report, July 1997, 8 .

23 Ibid.

24 Federal Highway Administration, Transportation Studies Division, Highway Revenue and Pricing Team, Congestion Pricing Notes, no. 3, (Washington, DC: Federal Highway Administration, Fall 1997), 1.

25 Edward C. Sullivan and Joe El Harake, "The CA Route 91 Toll Lanes - Observed Impacts and Other Observations," presented at the 77th Meeting of the Transportation Research Board, January 11-15, 1998, (Washington DC: Transportation Board, 1998), 5, 11.

26 Fielding and Klein, Access, 13.

27 lbid.

28 "Value Pricing: Paying Premium Price for Premium Highway Service," Innovation Briefs, (Washington, DC: Urban Mobility Corporation, March/April 1998), 2.

29 Fielding and Klein, Access, 13.

30 John T. Berg, "The Congestion Pricing Pilot Program: Experience and Prospects," (The Federal Highway Administration, Office of Policy, Highway Pricing Team, Washington, DC: Federal Highway Administration, 1997), 6.

31 Federal News Service, "Prepared Statement of Jane F. Garvey, Acting Administrator, Federal Highway Administration, U.S. Department of Transportation, Before the Senate Committee on Environmental and Public Works, Transportation and Infrastructure Subcommittee," 6 June 1997, Washington, DC: Federal Information Systems Corporation, 1997, 1.
32 Ibid., 1.

33 Ibid., 1.

34 National Capital Region Transportation Planning Board, "Woodrow Wilson Bridge Improvement Study: Regional Travel Demand Analysis," Executive Summary, Washington DC: Metropolitan Washington Council of Governments, May 1996, 8.

35 Survey based on drivers of San Diego's Interstate 15 HOT facility. See Fielding and Klein, Access, 13.

36 Reid, "A Hot Alternative to the Slow Lane?" 19 March 1998, B1.

37 Todd Litman, "Using Road Pricing Revenue: Economic Efficiency and Equity Consiclerations," Transportation Researcb Record: Planning and Administration, Number 1558, (Washington DC; National Research Council, 1996), 25.

38 Ibid.

39 Ibid. 25.

40 Karen T. Frick, Steve Heminger, and Hank Dittmar, "Bay Bridge CongestionPricing Project: Lessons Learned to Date," Transportation Researcb Record: Planning and Administration, 1558, Washington DC: National Research Council, 1996, 32.

41 Ibid.., 32.

\section{Bibliography}

Ayers, B. Drummond, Jr. "A Toll Road in California Offers a High-Tech Answer to Traffic." The New York Times, 2 January, 1996.

Berg, John T. "The Congestion Pricing Program: Experience and Prospects," The Federal Highway Administration, Office of Policy, Highway Pricing Team. Washington, DC: Federal Highway Administration, 1997.

Bhatt, Kiran \& Higgins, Thomas. Final Report. An Assessment of Travel Demand Management Approacbes to Suburban Activity Centers, Washington, DC: U.S. Department of Transportation, 1989. 
Cervero, Robert. Suburban Gridlock. New Brunswick, New Jersey: Center for Urhan Policy Research, 1986

Cervero, Rolkert. Working Paper 583. Transfortation Alternaties in a Congestion l'ricing lintironment. Berketey. California: Iniversity of Galifomia at Berketey Institute of Uthan and Regional Development/National Transit Access Center. 1\%g2.

Downs, Anthony. Ne'w Vistons far Metropolitan Amertica. Washingten, OC: The Brorkings Institution, 1994.

Downs, Anthony. Stack in Traffic: Coping with peak-hutr iraffic congestion. Washington, DC: The Brookings Institution, 1992

"Electronic "Ioll Collection," Available from http://www path berkeley edu/ -leap...ct ronic_Payment/electron_toll.html; 5 March 1998

Federal Highway Administration, Transportation studies Division, Highway Revenue and Pricing Team. Congestion Pricing Notes, no. 3 (Washington, DC: Federal Highway Administration, Fall 1997).

Federal Highway Administration, Transportation Studies Division, Highway Revenue and Pricing Team. Congestion Pricing Pilot Program: Overview and Status Report, 1997.

Federal News Service. "Prepared Statement of Jane F. Garvey, Acting Administrator, Federal Highway Administration - US. Department of Transpontation hefore the Senate Committee on Environment and Public Works, Transportation and Infrastructure Subcommittex." Federal Information Systems Corporation, 6 June 1997

Ficlding, Gordon J. \& Klein, Daniel B. "HOT Lanes: Introducing Congestion Pricing One lane at a Time." Access, no. 11 (Fall 1997).

Fielding, Gorckn J. "Congestion Pricing and the Future of Transit." Joumal of Transpont Geography, 3, no, 4, (1995): 239-246 (Reprint: The University of California Transportation Center, University of Californis at Berkeley).
Frick, Karen 'T., Heminger. Steve and Dittmar, Hank. "Bay Bridge Congestion-Pricing Project: Lessons Learned to Date." Transportation Researcb Record: Planning and Administration, 1558 (Washington. DC: National Research Council, $19 \%($ ).

Greater Washington Board of Trade: Traniportation Study. Avatilable from htlp. www washingtonpost.com/wpsrv Iexal daily/april/23/hothtml, INTERNEI

Gottman, Jean \& Harper, Rohert A., editors. Metropolis an the Mone: Gegaraphers lisk at urban spraul. New York, New York: Wohn Wiley \& Sons, Inc., 1967.

Institure of Transportation Studies (ITS) International, University of California at Berkeley. Available from HYPERLINK http: /www.path.berkeley.edu/leap...ctr onic_Payment/electron_toll.html

Institute of Transportation Engineers (ITE) Task Force on High-Occupancy/Toll (HOT) Lanes. High-Occupancy/Toll (HOT) lanes and Value Pricing: $A$ Preliminary Assessment, Draft Report. Washington, DC: March 26, 1998.

K.T. Analytics, Inc. Congestion Pricing: Guidelines for Project Development. Revised Interim Report. Sponsored by Fecleral Highway Administration. Washington, DC: August 1996.

Levinson, Herbert \$. "Freeway Congestion Pricing: Another look." Transportation Researcb Record: Pricing. Economic Denelopment. Cost Analssis, Transportation Impacts, and Transportation Managemenl Processes, 1450. Planning and Administration. Washington, DC: National Research Council, Transportation Research Board, 1995.

Litman, Todd. "Using Road Pricing Revenue: Fconomic Efficiency and Equity Considerations." Transportation Research Record: Planning and Administration, 1995. 
National Research Council, Committee for Study on Urban Transportation Congestion Pricing. Committee Report and Recommendations. Special Report 242. Curbing Gridlock: Peak-period fees to relieve traffic congestion. Vols. one and two. Washington, DC: National Academy Press, 1994.

National Research Council, Transportation Research Board. Road Pricing for Congestion Management: A Survey of International Practice. NCHRP Synthesis 210: A Synthesis of Highway practice. Washington, DC: 1994.

O'Harrow, Robert Jr. "Study Says Area Drivers to Lose 100 hours, $\$ 2,115$ a Year." The Washington Post. Sec. D1. Available from http://www.washington post.com/wp-srv/local/claily/april/24/ botreport.html, 24 April 1997.

Orski, C. Kenneth. Presentation by Mr. C. Kenneth Orski, Editor of Innovation Briefs and Chair, I'TE Task Force on HOT Lanes. Briefing on the Institute of Transportation Engineers (ITE) Report. High-Occupancy/Toll (HOT) Lanes and Value Pricing: A Preliminary

Assessment to the Technical Committee of the National Capital Region

Transportation Planning Board, March 6, 1998.

Owen, Wilfred. The Metropolitan Transportation Problem. Washington, DC: The Brookings Institution, 1956.

Reid, Alice. "A HOT Alternative to the Slow Lane?" The Washington Post, 19 March $1998, \mathrm{~B} 1$.

Reid, Alice. "Area Traffic Stuck in a Costly Jam." The Wasbington Post, 10 December 1996, A1.

Research and Policy Committee of the Committee for Economic Development. Developing Metropolitan Transportation Policies: A guide for local leadership. New York, New York: 1965.
Sullivan, Edward C. The California Route 91 Toll Lanes - Observed Impacts and Observations. Department of Civil and Environmental Engineering, California Polytechnic State University. San Louis, California: 1998.

"Value Pricing: Paying Premíum Price for Premium Highwaly Service." Innovation Briefs, (March/April 1998). 